\title{
Identity Formation of TEFL Graduate Students through Oral Discourse Socialization
}

\author{
Parviz Ahmadi \\ Universiti Putra Malaysia, Malaysia \\ Arshad Abd Samad \\ Universiti Putra Malaysia, Malaysia \\ Nooreen Noordin \\ Universiti Putra Malaysia, Malaysia
}

\begin{abstract}
This paper reports on academic discourse socialization of several EFL teachers in a TEFL graduate program in Iran through oral discourse practices over the first year of the program. It explores how the professional identity of the in-service teachers is affected by the socialization process, their prior histories and contextual factors. It concludes that dialogical interactions through oral discourse practices are likely to result in re-consideration of their prior professional identity. The paper is likely to make a contribution to our understanding of professional identity construction of EFL teachers in graduate programs as far as academic oral discourse practices are concerned.
\end{abstract}

Index Terms—academic discourse socialization, EFL teachers, professional identity

\section{INTRODUCTION}

As indicated by Lave \& Wenger (1991), identity, knowing and community enculturation are accompaniments to each other and the extent of disciplinary participation can influence the development of disciplinary identity. Development of teacher identity in second language teacher education is a new research area (Choi, 2007; Mantero, 2007; Peirce, 1995; Varghese, Morgan, Johnston, \& Johnson, 2005). Teachers` professional identity has been considered as a component of professional development by several researchers (e.g.,Freeman \& Johnson, 2005; Palmer \& Christison, 2007; Tarone \& Allwright, 2005). The construction of teachers' professional identity and its development, teachers' views toward their professional roles, and the connection between their views of their professional roles and their self-image have also attracted the attention of a number of researchers (e.g.,Beijaard, Meijer, \& Verloop, 2004; Woods \& Jeffrey, 2002).

While the professional identity of teachers has attracted a lot of researchers during the last decade, the formation of a professional teacher identity in a TEFL graduate program through engagement in discourse practices has largely remained unnoticed. Investigating the professional identity construction of student teachers, especially in EFL settings has remained neglected. Professional Identity construction of NNES student teachers in their own settings is an area of research which needs more investigation. Despite the importance of this issue in studies on discourse communities, few studies have investigated it among non-native English-speaking teachers in their professional discourse communities (e.g.,Tsui, 2007). Since these teachers may experience unique challenges due to their "dual identities" of being both L2 learners and teachers as Lim (2011) argues, it is probable that their identity construction should gain more significance in L2 teaching research. Most studies deal with NNES student teachers who are educated in English speaking countries and there are few studies addressing their professional identity formation in a second language context(e.g., Shin, 2008).

\section{METHODOLOGY}

The study is to investigate how student teachers' engagement through discourse socialization practices in their graduate TEFL program influence their professional identity and how much student teacher's prior sense of professional identity undergoes change and transition. The participants of this study were five first-year TEFL graduate students who were also English teachers in their local area. The in-service student teachers registered for Teaching Methodology and Teaching English Skills Courses in a public university in Iran. Data for the study were collected over two academic semesters, fall semester and spring semester 2012. The two courses were taught by the same NNEST university lecturer and the practicum was supervised by another instructor in the second semester. Data was collected by the researcher, during the fall and winter semesters for about eight months. The two courses focused mostly on oral discourse practices including small group discussions, and less attention was paid to written discourse practices. Apart from the group discussions, the oral presentations and microteachings were followed by interactions. The classroom procedures and practices in the courses of Methodology of TESOL and Teaching English Skills were similar as both courses were 
taught by the same instructor. The student teachers gave oral presentations, engaged in whole-class discussions after oral presentations, did task-based small group discussions and wrote reflection papers on the assigned reading materials.

The data sources for this study included classroom field-noted observations, audio-recorded individual interviews with student teachers and their instructors as well as small-group discussions and micro-teachings followed by questions and answers. The real spoken discourse and perspective of the participants during group discussion and the debates after micro-teaching were used as the main source of academic discourse socialization (Duff, 2002; Morita, 2002). The participants' learning and teaching experiences reflected in their emic viewpoints expressed in small-group discussions and microteaching follow-up discussions all provided a rather comprehensive image of their academic discourse socialization. After audio-recording the interviews and transcribing them, a constant comparative method (Glaser \& Strauss, 1967; Jones, Torres, \& Arminio, 2006) was used to analyze the data.

The present study aims at examining the influence of participants' engagement in discourse socialization practices during their first-year of graduate TEFL program on their professional identity construction and transition. Since teachers' belief is likely to influence their teaching practices (Richards \& Lockhart, 1994), uncovering their own view towards professional identity and its place in their academic discourse communities can be of more significance. The study focuses specifically on Iranian students as studies have shown that cultural difference may affect willingness to participate and collaborate in class activities including oral discourse practices (Amirkhiz et al. 2013, Hofstede, 1986).

\section{RESUlTS \& ANALYSIS}

\section{Negotiating identity through dialogical interactions}

The epistemic stance of the student teachers in their preliminary interviews as well as in their small-group discussions showed how they lived up to the self-images as EFL teachers they created mainly based on their personal histories. The following epistemic markers in the excerpts from their group discussions and their individual interviews can clearly show how they positioned themselves as legitimate discourse community members:

- My personal experiences show that ....

- According to my knowledge about high school students, I can say that....

- We are English teachers and it is obvious that ....

- As an English teacher, I know how to....

Through engagement in classroom group discussions, the student teachers had the chance to voice their professional self, which was a mixture of their prior learning and teaching experiences. They were in-service teachers, who assumed a professional role for themselves in their local professional community as it was reflected in their group discussions. Since the students contributed their ideas on some pedagogical issues raised in the group discussions, they made use of their foreign language teaching and learning experiences. This could help them form their professional identities as relative theorizers, decision-makers and experts in their local discourse community, which could confirm the situated nature of their identity formation in discourse communities. Engagement in group discussions had a very significant influence on the identity construction of the participants. The participants assumed more professional identity over time due to engagement in new discourse and practices. The following excerpts from their second semester discussions shows how they positioned themselves as more professional members of their community after their first year of their graduate program. The student teachers' perceptions of their professional identity varied as their self-images as an EFL teacher differed over the period:

- I think we have been discussing a lot of things during this time. I myself have learned many things. I have more confidence now and with no doubt I have become a better teacher, not just because of the texts I have read but I have learned many things from my classmates.

- The discussions helped me a lot. I learned many things. As an English teacher, I must say, I have become more qualified and more knowledgeable.

The group discussions during the period helped them to reconsider their understanding of their new professional identity shift. This confirms Cooper and Olson's (1996) findings that teacher's identity is a continuous process of being informed, formed, and reformed which develops over time mostly through having interactions with other members of their discourse community and also through reflection over teaching practices. Also, the findings of the study showed that the notions like self-perception and professional identity are dynamic and are subject to change over time due to situational factors (Tsui, 2008; Varghese et al., 2005) as it was specifically seen in cases of high school teachers who started teaching in English institutes to feel their professional role.

The findings showed their engagement in group discussions let them voice their professional identity more freely, which helped them feel a sense of community while they were engaged in group discussions. Signs of identity transitions could be seen in their discussions and also in their reports and reflection papers. Over time, they argued, claimed and recommended like relative experts as the following epistemic markers such as "I personally think", " As an English teacher", "As far as I know" can show their epistemic stance signaling their identity negotiation and positionalities. This sense of professional identity, although present in some of the group discussions from the beginning, became stronger over time. Morita (2004) has suggested that the way students in discourse communities 
negotiate their roles and identities is part of their academic socialization. The concept of community of practice sees identities as co-constructed through the ongoing collective negotiation of competence and practice in the process of learning and becoming (Eckert \& Wenger, 2005; Wenger, 1998).

Negotiating their positions in the discourse community through interactions with experienced members of their community and the disciplinary texts, the student teachers went through the process of identity formation as a legitimate member of their discourse community (Lave \& Wenger, 1991). After the first year, they could identify themselves as legitimate members of their EFL discourse community who could make a difference although this sense of community was not seen so evidently at the beginning. The participants experienced the professional transition and shift as all of them saw themselves as individuals who could be more contributing to their local EFL community and by voicing their professional self in the professional small group discussions, they could create a space for their active participation in their EFL discourse community as the following excerpts from the interviews can show, by developing their professional self and asserting membership, they could even suggest ways to form professional gatherings to discuss their issues:

- Holding such group discussions in English institutes can help very much because it is an opportunity for discussing the challenges and also an opportunity to improve our speaking skill and teaching knowledge.

- We need an association of English teachers who work at English institutes which can make us come together. It can organize many activities for EFL teachers and help us become more up-to-date. There should be a place where we can come together and talk about problems and solutions.

The student teachers' participation in dialogical interactions with their peers facilitated their reflection towards their own professional beliefs and practices and resulted in a pedagogical self (Bakhtin, 1981) from which they could negotiate their identity increasingly and assert themselves as legitimate members (Wenger, 1998) in the graduate program. According to social theory of identity formation proposed by Wenger (1998), dialogical interaction between the members of a discourse community plays a pivotal role in forming and shifting the identities of community members. Based on sociocultural perspective towards teacher education, the process of learning to teach is more concerned with identity construction and transition rather than a process in which knowledge is accumulated by student teacher (Varghese et al., 2005). Therefore, the reconstruction of student teachers' identity in teacher education program can be seen as a major purpose in these programs (Singh \& Richards, 2006).

The participants were in-service teachers in a local Iranian EFL setting. This context was isolated in regard to lack of any supportive in-service training based on what both the student teachers and their instructors stated, the oral discourse socialization practices over the two semesters could make them feel like they improved their professional self through having interactions with their colleagues in the same context. They found it as the only way to associate with their colleagues and share a sense of identity.

- Whenever I am here and I discuss the teaching problems with my friends, I feel more I am a teacher and I should find ways to help my students improve their English. I feel all teachers should have chances like this to talk and discuss. It helps a lot. This is the time you really realize you are a teacher.

\section{Identity formation through apprenticeship of observation}

The interviews with the participants also showed that teachers' professional identity construction was influenced more by the personal histories and prior beliefs concerning teaching and learning a foreign language than accumulating pedagogical and theoretical knowledge in pre-service teacher education courses or through traditional professional development programs (Richardson, 2003),

I remember how I learned to pronounce the words correctly. For learning the phonetic symbols, I first tried to learn the phonetic symbols using an Oxford Advanced English Dictionary and then I wrote the phonetic symbols under each word and then tried to pronounce them according to the symbols.

The way I teach grammar may be different from my colleagues because I try to make my students make sentences with the new grammar structures instead of focusing on the exercises in the book.

Prior educational experiences they had gained through 'apprenticeship of observation' were another determining factor influencing their professional identity formation. The findings obtained from the first interview at the beginning of the program showed that the personal history and beliefs of the student teachers affected by their learning and teaching experiences played a great role in forming their professional identity before they take their courses. Previous learning and educational experiences of the students played a major role in shaping such an image. Their teaching experiences also had shaped the image they maintained.

The personal practical knowledge the student teachers, who were also in-service English teachers, gained through teaching in various educational settings also signaled their idiosyncratic understanding of learning and teaching theories and practices. Their solutions for the pedagogical challenges during in-class discussions showed how their understanding of learning and teaching issues could influence their professional identity formation,

- Learning English is like other skills. Practice is very important. My experience tells me when you stop practicing, you may forget many things. Even when they are at home, they should listen and read. They should have input when they are at home, in their car or at work. Input helps the language stay on standby.

- When I was learning English, I used to underline the expressions and then I tried to use them in new sentences and then I imagined I was talking to someone in English and it was very good because there was no one I could speak to 
most of the time but it helped me to feel am really using them. Now I sometimes tell my students to try this when they go home.

The findings are aligned with the results obtained from the previous studies on student teacher's identity formation showing the impact of their conceptions of their professional role as a teacher (Golombek, 1998; Tsui, 2007, among others).Individual teachers' conceptions of their professional identity were uncovered more during the debates and small group discussions, especially when they made inter-contextual connections between their own prior practical knowledge and pedagogical issues. This is in line with the suggestion made by Coldron and Smith (1999) on knowing teachers' identity through a holistic view obtained from interactions between individual selves of the student teachers and their wider socio-political settings.

\section{The role of contextual factors in seeing professional self}

Contextual factors were seen as hindering factors preventing the student teachers from adopting and embracing pedagogical practices in harmony with their conceptual images of modern ways of learning and teaching a foreign language.These studies show how contextual factors including administrative and institutional ones influence their decision-making processes. As the excerpts show, the way the participants positioned themselves in their local society, however, was undermined by their sociopolitical context. Since the policies set in the public schools marginalized the way the student teachers positioned themselves in their local EFL discourse community, the recommendations towards the challenges they faced in such settings were scarce or more conservative compared to the ones they handled in private centers.

The traces of contextual factors and the micropolitics (Van den Berg, 2002) of the settings where they were engaged in teaching could be detected when it came to their recommendations regarding their challenges in their EFL settings. As stated by Hargreaves (1988), teachers' practices can be associated with their contextual factors in which they participate,

Teachers do not just decide to deploy particular skills because of their recognized professional worth and value, or because of their own confidence and competence in operating them. Rather they make judgments about the fit between particular skills, constraints, demands, and opportunities of the material environment of the classroom; about the appropriateness of particular styles or techniques for present circumstances (p. 219).

The following excerpts from the writings of two high school teachers show how the institutional policies can impact the way they could see their positions in their community and their agency towards participating in its practices.

- Using supplementary materials to make up for the weak points in the books is practically impossible because there is no time to work on the materials and on the other hand, because some of the students go to English institutes and some don't, there are many levels of English in the same class, so it is not easy to do on the same material in a high school English class. Also, few high school classes are equipped with computers for listening to supplementary materials. You can only follow the book and try to make the students familiar with new vocabularies and structures as much as possible.

- Some of the students are very reluctant and are not interested in English in my classes. They just want to pass the courses by memorizing the vocabularies and grammar of the lessons. That's why I think it might be difficult to implement such strategies in real classes. The first thing to be done about it is to motivate the learners. I think it is very difficult because the books are boring and no one is thinking of any change.

The role of institutions and their expectations also affected their practical experiences and consequently how they could see their professional self. The reflective writing of the student teachers helped them reconstruct their professional identity as a major part of professional development (Varghese, Morgan, Johnston, \& Johnson, 2005). They sounded more like relative experts, especially when recommending innovative solutions to pedagogical issues in their local EFL setting. The following excerpts can indicate how they prescribed ways to deal with the challenges in their educational context,

- There are many controversies about the role of grammar in EFL classes, but as far as I am concerned English teachers should pay enough attention to grammar because it is the skeleton of speech and writing.

- The teachers must want the students to read story books which are suitable for their level. The teacher can make them read a story book each week until they get used to reading much. I personally know this is true for my students. A teacher sometimes should put pressure to form a habit. Then, you just continue with the habit very smoothly and constantly.

The roles promoted by the education office as well as by private English centers also affected the way the student teachers saw their professional self. The conflicting perspectives between the views of administrators and those of the English teachers towards learning and teaching foreign languages had a substantial role in their image of EFL teachers' professional identity in their local context. The sociocultural setting can have an overwhelming influence of their socialization and even their professional identity formation of EFL teachers based on the expectations of the educational milieu (Beijaard et al., 2004; Golombek, 1998; Tsui, 2007) as the following excerpt from an interview with one of the participants can show:

- It is better at institutes, at least they sometimes accept your words or they convince you why they do something, but in high schools they don't know about the purposes of teaching a language and they just insist on following the book and making the students ready for the final exams. They think if they want to learn speaking they should go to institutes 
and not in high schools. They have become hopeless about public schools for teaching speaking and listening. They say it is the duty of institutes.

Their conception of their professional identity was mainly limited to their EFL context at the beginning and their development in understanding TESOL issues through disciplinary texts slightly modified their understanding of their position in the wider community of TESOL.

- I think this can be very useful for all English learners and more research can be done on teaching collocations and its effect on writing at upper-intermediate and advanced levels.

- I think follow-up communicative activities for reading passages have not been given enough attention because most of them don't seem to be very communicative. There should be more communicative activities and the ESL or EFL researchers must find more interactive and even more motivating practices for post reading tasks.

Over the time, their small-group discussions as well as their debates demonstrated they gradually developed critical reflection towards their own professional identity and how they could see their own positions in their own local EFL community. However, they had little sense of a wider community of TESOL and saw no necessity to engage in practices beyond their local community as there was no motive in their EFL educational setting which could probably encourage them to assert a wider TESOL community membership. Lack of writing support centers and writing tutors discouraged the in-service student teachers from participating in the practices of international; TESOL discourse community through writing for publication.

\section{CONCLUSIONS \& IMPLICATIONS}

The findings made it evident that the process of in-service teachers' identity formation was a non-stop reciprocal interaction between factors including prior learning and teaching experiences, knowledge obtained from academic discourse practices and their real fieldwork experiences. According to Markee (2004), "second language classrooms are not just learning places; they are, just as importantly, social places" (p. 593). Encouraging dialogical interactions in TEFL graduate classes as sociocultural contexts can play a significant role in professional development of EFL teachers and their formation of pedagogical self (Bakhtin, 1981).

The absence of motives for graduate students to take part in the international TESOL community practices such as presenting papers in national or international conferences, writing for publication or applying for membership in TESOL-related associations or organizations were among the shortcomings which may be found in other EFL communities as well. Providing support centers can help EFL graduate learners assert their legitimate peripheral participation in the practices of the TESOL discourse community worldwide.

Enough opportunities should be provided for in-service teachers in graduate programs to be more in contact with their colleagues, more experienced members of their local EFL community and even more established insiders in TESOL community. These opportunities can help strengthen social networking among less experienced community members and its old-goers for the final purpose of facilitating the development of professional identity among preservice or in-service teachers. Such opportunities can be provided through encouraging non-formal group meetings between EFL teachers to create a stress-free setting where professional knowledge and fieldwork experiences can be shared smoothly. A non-affiliated club of EFL teachers which accepts members through subscription and managed by elected members can lower the anxiety of many inexperienced teachers dealing with professional issues.

Future research can focus on narrative case study so that it can uncover the personal history of the teachers more in detail. The findings would probably help understand the influence of economic, political, social and educational factors on professional development of both pre-service and in-service teachers based on socio-cultural theories of learning and a longer study which can track the long-term changes and professional development of graduate students throughout the program and even the following years after the program can illuminate how professional beliefs, knowledge and identity of second language teachers can be subject to change due to more participation in the practices of TESOL discourse community.

\section{REFERENCES}

[1] Amirkhiz, S. Y. Y., Kamariah Abu Bakar, Arshad Abd Samad, Roselan Baki, \& Leila Mahmoudi. (2013). Teachers' experiential reflections on Iranian and Malaysian students collaborative orientations. Asian Social Science, (9), 1, 271-277.

[2] Bakhtin, M. M. (1981). The Dialogic Imagination, ed. michael holquist, trans. Caryl Emerson and Michael Holquist. Austin: University of Texas Press.

[3] Beijaard, D., Meijer, P. C., \& Verloop, N. (2004). Reconsidering research on teachers' professional identity. Teaching and Teacher Education, 20(2), 107-128.

[4] Choi, S. (2007). The experiences of non-native English speaking teachers and their professional identity constructions in an ESL context: Pro Quest.

[5] Coldron, J., \& Smith, R. (1999). Active location in teachers' construction of their professional identities. Journal of Curriculum Studies, 31(6), 711-726.

[6] Cooper, K., \& Olson, M. R. (1996). The multiple 'I's' of teacher identity. Changing research and practice, 78-89.

[7] Duff, P. (2002). The discursive co-construction of knowledge, identity, and difference: an ethnography of communication in the high school mainstream. Applied linguistics, 23(3), 289-322.

[8] Eckert, P., \& Wenger, E. (2005). Communities of practice in sociolinguistics. Journal of Sociolinguistics, 9(4), 582-589. 
[9] Freeman, D., \& Johnson, K. E. (2005). Towards linking teacher knowledge and student learning. Language teacher education: International perspectives on research and practice, 73-95.

[10] Glaser, B. G., \& Strauss, A. L. (1967). The discovery of grounded theory: Strategies for qualitative research. Chicago: Aldine.

[11] Golombek, P. R. (1998). A study of language teachers' personal practical knowledge. Tesol Quarterly, 32(3), 447-464.

[12] Hargreaves, A. (1988). Teaching Quality: a sociological analysis 1. Journal of Curriculum Studies, 20(3), 211-231.

[13] Hofstede, G. (1986). Cultural differences in teaching and learning. International Journal of Intercultural Relations, (10), 3 , 301-320

[14] Jones, S. R., Torres, V., \& Arminio, J. L. (2006). Negotiating the complexities of qualitative research in higher education: Fundamental elements and issues: Brunner-Routledge.

[15] Lave, J., \& Wenger, E. (1991). Situated learning: Legitimate peripheral participation. Cambridge, UK: Cambridge University Press.

[16] Lim, H. W. (2011). Concept maps of Korean EFL student teachers' autobiographical reflections on their professional identity formation. Teaching and Teacher Education, 27(6), 969-981.

[17] Mantero, M. (2007). Identity and second language learning: Culture, inquiry, and dialogic activity in educational contexts. Greenwich, CT: Information Age Publishing.

[18] Markee, N. (2004). Zones of interactional transition in ESL classes. The Modern Language Journal, 88(4), 583-596.

[19] Morita, N. (2002). Negotiating participation in second language academic communities: A study of identity, agency, and transformation: University of British Columbia.

[20] Morita, N. (2004). Negotiating participation and identity in second language academic communities. Tesol Quarterly, 38(4), 573-603.

[21] Palmer, A. S., \& Christison, M. A. (2007). Seeking the heart of teaching: University of Michigan Press.

[22] Peirce, B. N. (1995). Social Identity, Investment, and Language Learning. Tesol Quarterly, 29(1), 9-31.

[23] Richards, J. C., \& Lockhart, C. (1994). Reflective teaching in second language classrooms: Cambridge University Press.

[24] Richardson, V. (2003). The dilemmas of professional development. Phi Delta Kappan, 84(5), 401-407.

[25] Shin, S. J. (2008). Preparing non-native English-speaking ESL teachers. Teacher development, 12(1), 57-65.

[26] Singh, G., \& Richards, J. C. (2006). Teaching and learning in the language teacher education course room: A critical sociocultural perspective. RELC Journal, 37(2), 149-175.

[27] Tarone, E., \& Allwright, D. (2005). Second language teacher learning and student second language learning: Shaping the knowledge base. Second language teacher education: International perspectives, 5-24.

[28] Tsui, A. (2007). Complexities of identity formation: A narrative inquiry of an EFL teacher. Tesol Quarterly, 41(4), 657-680.

[29] Tsui, A. (2008). Classroom discourse: Approaches and perspectives. The Encyclopedia of Language and Education, 6, 261-272.

[30] Van den Berg, R. (2002). Teachersâ€ $€^{\mathrm{TM}}$ meanings regarding educational practice. Review of educational research, 72(4), 577625.

[31] Varghese, M., Morgan, B., Johnston, B., \& Johnson, K. A. (2005). Theorizing language teacher identity: Three perspectives and beyond. Journal of language, Identity, and Education, 4(1), 21-44.

[32] Wenger, E. (1998). Communities of practice: Learning, meaning, and identity: Cambridge University Press.

[33] Woods, D., \& Jeffrey, B. (2002). The reconstruction of primary teachers' identities. British journal of sociology of education, 23(1), 89-106.

Parviz Ahmadi is a PhD student in TESL at the Faculty of Educational Studies, Universiti Putra Malaysia.

Arshad Abd Samad is an Associate Professor at the Department of Language Education and Humanities, Faculty of Educational Studies, Universiti Putra Malaysia.

Nooreen Noordin is a Senior Lecturer at the Department of Language Education and Humanities, Faculty of Educational Studies, Universiti Putra Malaysia. 